\title{
The Ultrastructure of Sporogonic Stages and Spores of Thelohania and Plistophora (Microsporida, Nosematidae) from Simulium ornatum Larvae
}

\author{
By M. S. S. GASSOUMA* \\ Department of Entomology, London School of Hygiene and Tropical Medicine \\ AND D. S. ELLIS \\ Electron Microscope Laboratory, London School of Hygiene and \\ Tropical Medicine, London WCI ${ }_{7} H T$
}

(Received I2 June 1972; revised 24 August 1972)

\begin{abstract}
SUMMARY
The sporogonic stages and spores of Thelohania and of Plistophora from Simulium ornatum larvae were examined with the electron microscope. The two species of Thelohania studied appeared morphologically similar apart from spore size and the number of polar filament coils within the mature spore. The first species, Thelohania minuta (Gassouma, 1972), had four to five coils, while the second, $T$. canningi (Gassouma, 1972), had nine to ten. These mature filaments were found to have an internal structure and their polar cap was not directly attached to the internal spore wall. The varied membrane systems, including polaroplast, Golgi apparatus and endoplasmic reticulum of each stage are described. The Plistophora species, Plistophora tillingbournei (Gassouma, 1972), had 20 to 2 I polar filament coils within the mature spore. The complex wall of sporoblast and spore of this species is compared with the smooth one found in the two Thelohania species.
\end{abstract}

\section{INTRODUCTION}

Previous electron microscope studies of microsporidans of Simulium have been made by Vavra, who (Vavra, 1965) studied three species of Thelohania, two of Plistophora and (Vavra, 1968) one of Caudospora.

Microsporida in hosts other than Simulium have been studied, many at ultrastructural level, by Huger (I960), Lom \& Vavra (I96I), Kudo \& Daniels (I963), Lom \& Vavra (I963), Lainson, Garnham, Killick-Kendrick \& Bird (I964), Vavra (I965), Lom \& Corliss (1967), Ishihara (1968), Sprague \& Vernick (I968a, b), Sprague, Vernick \& Bolivar (I968), Stanier, Woodhouse \& Griffin (I968), Vernick, Sprague \& Bolivar (I969), Sprague \& Vernick ( 1969 ) and Akao (1969). This paper describes and discusses certain morphological features of the species of Thelohania and Plistophora found in the larvae of Simulium ornatum.

\section{METHODS}

Most of the material used in this study came from Simulium ornatum larvae found in the River Tilling Bourne in Surrey, England. The larvae were parasitized by Plistophora tillingbournei (Gassouma, 1972) and also by Thelohania minuta (Gassouma, 1972) (mean spore dimensions, dry-fixed, $3.2 \mu \mathrm{m}$ by $2.9 \mu \mathrm{m}$ ). Other $S$. ornatum larvae, collected from the

* Present address: Eye Diseases and Filariasis Division, Ministry of Health, Khartoum, Sudan. 
River Lea in Hertfordshire, were parasitized by Thelohania canningi (Gassouma, 1972) (dry-fixed mean spore dimensions, $4.7 \mu \mathrm{m}$ by $3.6 \mu \mathrm{m}$ ).

Infected larvae were dissected to remove the intact spore masses, which were then immediately placed in one of the fixatives mentioned below.

The degree of penetration of the mature spore wall by stains and embedding media varied considerably with the fixatives used. The best results were obtained by using (i) $\mathrm{I} \cdot 2 \%$ potassium permanganate in saline for $4 \mathrm{~h}$, followed by postfixation staining with either $\mathrm{I} \%$ osmium tetroxide or uranyl acetate in saline for I h; or (ii) $3 \%$ glutaraldehyde in Rhodin and Zetterqvist's (R.Z.) buffer for $24 \mathrm{~h}$, postfixation staining with I \% osmium tetroxide in R.Z. for $4 \mathrm{~h}$, and further staining with phosphotungstic acid for $\mathrm{I} h$. The specimens were dehydrated through graded alcohols and embedded in Araldite via toluene. Sections were cut on a Huxley Cambridge ultramicrotome and viewed in a Zeiss E.M. 9 electron microscope.

\section{RESULTS}

Sporonts were found within disintegrating cells of the host's fat bodies, and multiple infection of individual cells was common.

\section{Sporoblast formation}

In the two Thelohania species the sporont nucleus was seen after the second and occasionally after the third division (Fig. I to 3). At this stage both species were morphologically similar and in both the final number of daughter nuclei was eight, the sporont reaching $20 \mu \mathrm{m}$ in size. The smooth sporont wall was 55 to $60 \mathrm{~nm}$ thick and made up of two distinct layers. Fig. I and 2 show this wall lining the deep clefts formed between the daughter nuclei surrounded by their accompanying cytoplasm. These clefts divided the sporont into lobules which remained attached to each other at the centre until the final division. The cytoplasm within each lobule was traversed by a very extensive membrane system, much of it arranged in parallel layers whose regularity, despite sectioning at various angles, was suggestive of extensive laminated plates (Fig. I). In other areas these membranes resembled typical endoplasmic reticulum. The large nuclei within the sporont were surrounded by a double membrane.

In Plistophora tillingbournei the sporont measured $3 \mathrm{I}$ to $33 \mu \mathrm{m}$. Its nucleus went through five division stages before the final sporoblasts were produced. Division of the nucleus was not followed by the compact lobulation found in the species of Thelohania, but instead the daughter nuclei moved peripherally with their accompanying cytoplasm giving rise to buds which separated from a central body. No cytoplasmic organelle was seen in early sporoblasts (Fig. 4), but a complex wall was discernible from the earliest division stages. This wall (Fig. 4,5 ) consisted of a smooth inner layer to which were attached a close-packed array of small tubules about $0 \cdot \mathrm{I}, \mu \mathrm{m}$ in diameter, surrounded by a thin outer membrane.

\section{Sporoblasts}

Early Thelohania sporoblasts were roughly spherical, with a wall still of the same thickness and electron-density as that of the original sporont (Fig. 3). Mature forms had thicker walls and were ovoid. Occasionally, before the sporoblasts were completely separated, the polar filament could be identified (Fig. I). In most mature sporoblasts it formed two or three coils. The anterior end of this filament was straight and ended in a vesicular sac (Fig. 3). Definite binucleation (diplokäryon) as seen by Vavra (1965) was not evident in these sporoblasts.

The Plistophora sporoblasts were variable in shape (Fig. 5, 6) and the polar filament was 

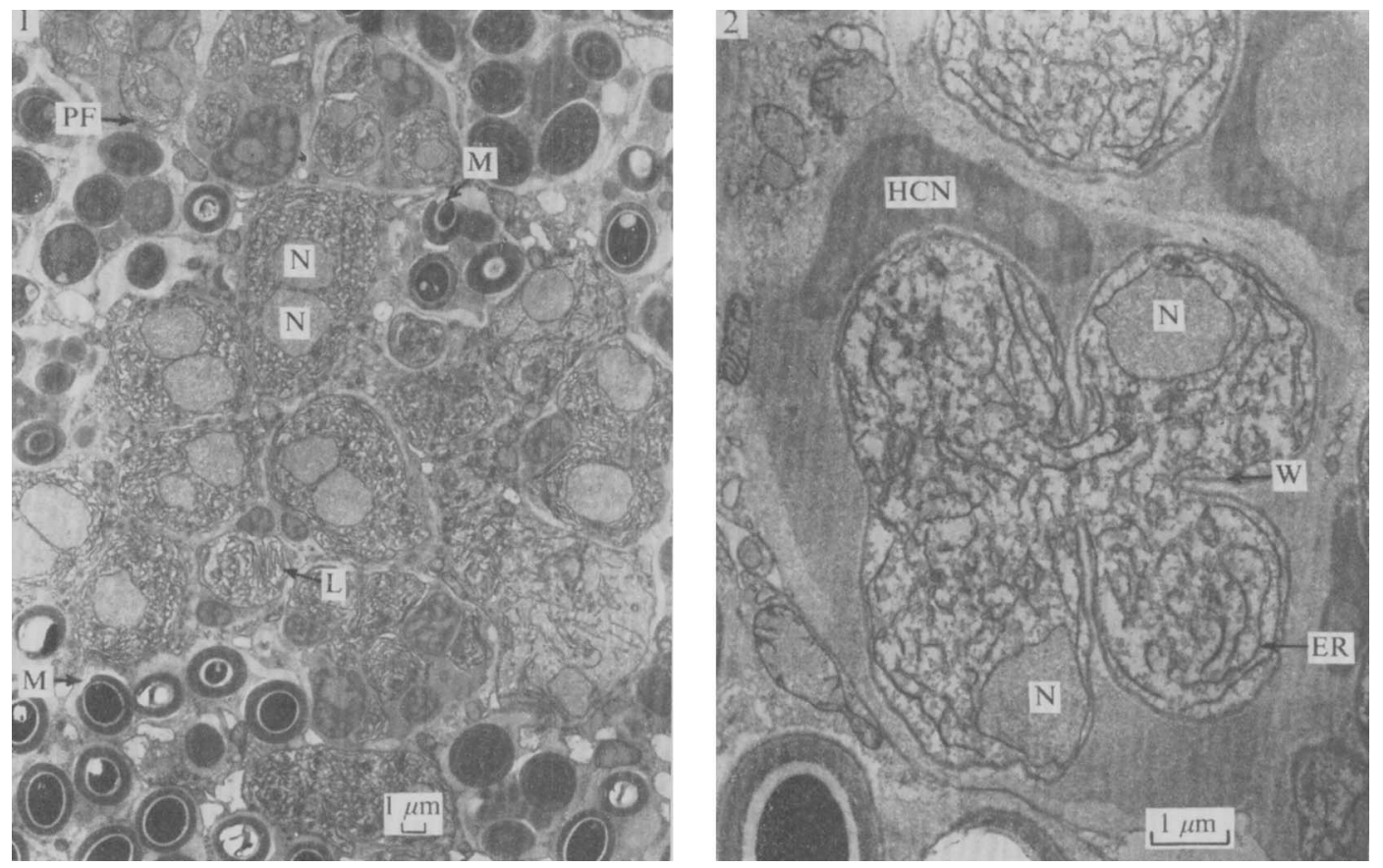

Fig. I. Section through a spore mass of Thelohania minuta, showing the deep clefts in dividing sporonts, their nuclei $(\mathrm{N})$, laminated plates (L), developing polar filaments (PF), sporoblasts and mature spores with micropyles (M).

Fig. 2. Section through a host cell parasitized by an early dividing sporont of Thelohania minuta, showing the deep infoldings of the sporont wall (W) to form clefts between the daughter nuclei (N), the extensive network of endoplasmic reticulum (ER) and host cell nucleus (HCN).

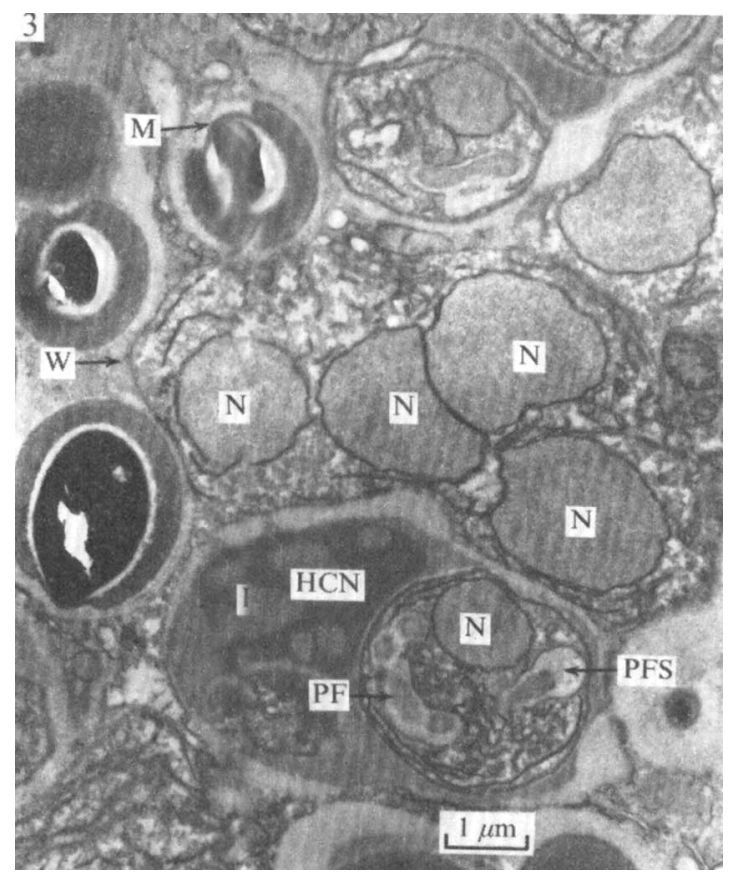

Fig. 3. Section from the same material as Fig. 2, showing four daughter nuclei in one cell and a sporoblast in the adjacent cell below. The sporoblast wall (W) is still one unit. The polar filament (PF) ends in a sac (PFS). The mature spores show prominent micropyles (M). The disintegrating nucleus (HCN) of the host cell is still evident. 
not seen in early forms (Fig. 4). More mature forms had up to eight coils (Fig. 5) and occasionally the membrane structures of a developing polaroplast were seen (Fig. 6). The cell wall of the mature sporoblast did not possess the outer thin membrane found over earlier developing forms (Fig. 4) and the tubules attached to the inner membrane measured up to $\mathrm{I} \mu \mathrm{m}$ in length (Fig. 5).

\section{Spores}

In both Thelohania species the spore wall could be identified after the main organelles were visible in the sporoblasts. At this stage the two species could be distinguished by the spore sizes, Thelohania minuta averaging $3.2 \mu \mathrm{m}$ in length (Fig. I) and T. canningi $4.7 \mu \mathrm{m}$. The Plistophora spores averaged $4.5 \mu \mathrm{m}$. All were oval in shape.

In Thelohania the cell wall consisted of a trilaminate envelope, the electron-dense inner and outer layers being $13 \mathrm{~nm}$ thick. The middle layer averaged about $165 \mathrm{~nm}$ but was thickened posteriorly to $200 \mathrm{~nm}$ and, at the anterior tip, was reduced over a small circular area to only $35 \mathrm{~nm}$. This thin area (Fig. 3, 8, I0, I I), called the 'micropyle' by Lom \& Corliss (1967), lay over the anterior end of the polar filament (referred to as the 'polar cap' by these authors).

The complex spore wall of Plistophora tillingbournei, laid down early in sporoblast formation, had a thickened inner layer in the mature spore. This electron-dense layer supported a mass of tubules up to $\mathrm{I} \cdot 5 \mu \mathrm{m}$ in length which were no longer lying parallel to each other (Fig. 5) but spread out in all directions beneath the disintegrating outer layer (Fig. I3). No 'micropyle' was seen.

In the mature spores of both species of Thelohania and in Plistophora, the polar filaments were of similar appearance. The extreme anterior end beneath the 'micropyle' appeared to be anchor-shaped in section, with the two arms extending back beneath the spore wall (Fig. IO, II, 13), but serial sections showed it to be mushroom-like in form.

Immediately behind this, the filament, surrounded by the polaroplast, became a straight tube, approximately I60 $\mathrm{nm}$ in diameter (Fig. IO, II, I3). On leaving the polaroplast the filament bore diagonally and reached the inner surface of the spore wall where, remaining in contact with the wall, it coiled posteriorly around the central sporoplasm. In some sections of the Thelohania species the filament appeared to end close to the nuclear membrane.

The mature spores of Thelohania minuta contained four to five coils of this filament (Fig. 8, 9); T. canningi had nine to ten coils (Fig. I I) and Plistophora tillingbournei 20 to 2I (Fig. 7).

The coils in Plistophora tillingbournei occupied the posterior half, and in the species of Thelohania the posterior third, of the inner spore wall surface.

The polar filament was circular in cross-section, and surrounded by a single membrane (Fig. 8, 9, II). Within this, in the species of Thelohania, were seen two to four concentric bands of contrasting electron densities whose arrangement appeared to change along the length of the tube as it coiled (Fig. 8, I2).

The polaroplast (Huger, 1960) was a complex organelle, similar in Thelohania and Plistophora, lying immediately behind the base of the polar filament (polar cap) and surrounding the straight part of the filament (Fig. 8, I I, I3). It was made up of a series of membranous lamellae or plates around the filament, their inner edges in continuity with the filament membrane (Fig. 8) and their outer edges joined in pairs (Fig. II), making up a series of flattened sacs, packed tightly together. The lamellae became smaller towards the posterior end of the polaroplast, which occupied roughly the anterior third of the spore in each species. 

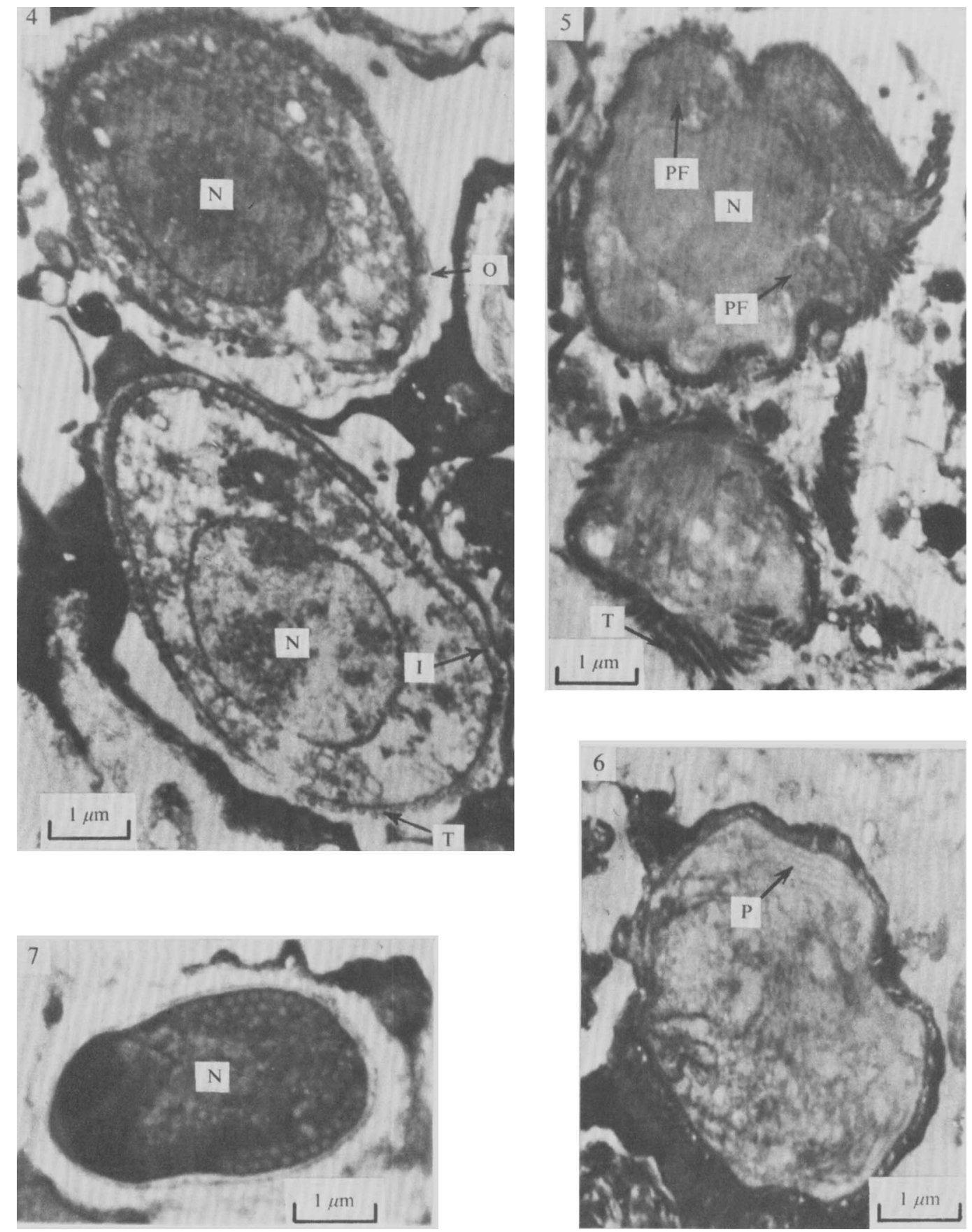

Fig. 4. Two early sporoblasts of Plistophora tillingbournei enveloped in the complex cell wall made up of three layers, inner (I), tubules (T) and outer thin layer (O). No cytoplasmic organelle is present.

Fig. 5. From the same material as Fig. 4. These mature sporoblasts have more developed cell walls and one contains a polar filament $(\mathrm{PF})$ of eight coils. The cell outline is irregular and the tubules $(\mathrm{T})$ of the wall are arranged parallel to each other.

Fig. 6. Sporoblast of Plistophora tillingbournei with laminated membrane plates of a developing polaroplast (P).

Fig. 7. A mature spore of Plistophora tillingbournei containing a polar filament with 20 coils. 


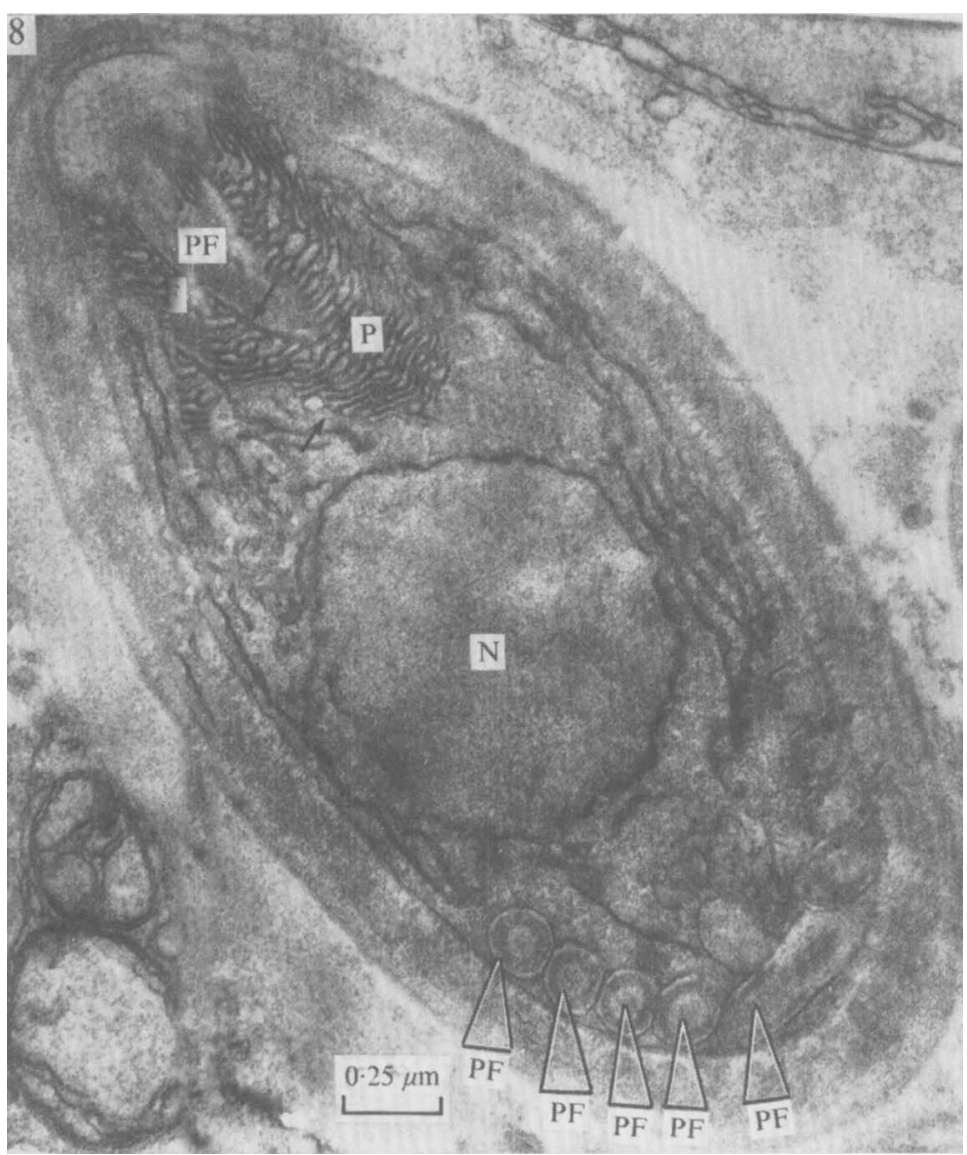

Fig. 8. A mature spore of Thelohania minuta, showing the spore wall made up of three layers, thicker at the posterior end and with a micropyle at the anterior end. The polar filament (PF) and its five coils contain material stained with $\mathrm{KMnO}_{4}$. The outer edges of the polaroplast (P) membranes are joined up (arrowed) while the inner edges join the membrane of the polar filament (also arrowed).

In Thelohania a narrow layer $(40 \mathrm{~nm})$ of cytoplasm was seen between the anterior end of the polar filament (polar cap) and the thin area of spore wall (micropyle). Although osmophobic (Huger, 1960; Stanier et al. I968), this area was visualized after potassium permanga nate fixation (Fig. 8, 9, 10).

The cytoplasm of the spore was traversed longitudinally by an extensive membrane system (Fig. 8, 9) having the appearance of a specialized endoplasmic reticulum. Areas of enlarged membranes and small vacuoles, lying between the polaroplast and the nucleus, appeared similar to a Golgi apparatus (Fig. I I). No mitochondrion was observed in any of the species examined. Two nuclear profiles were seen in several sections of the Thelohania spores (Fig. 9). 


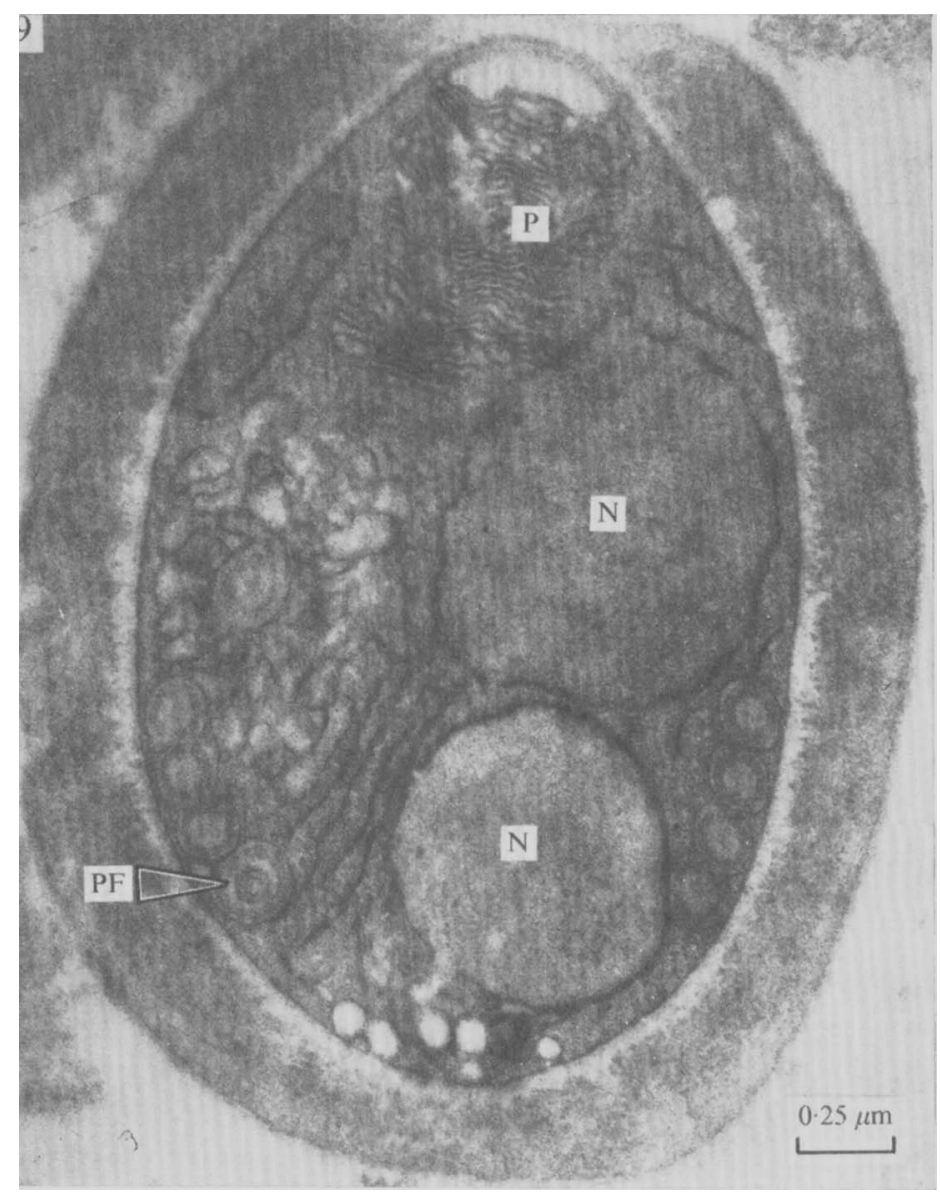

Fig. 9. A similar spore to that in Fig. 8, with two nuclear profiles (N).

\section{DISCUSSION}

Our studies of the two species of Thelohania revealed no difference in morphology apart from spore size and the number of polar filament coils (respectively four to five and nine to ten) within the mature spores. The Plistophora spores were intermediate in size between the two Thelohania species, and had a similar internal arrangement of organelles, though the polar filament coils were much more numerous (20 to $2 \mathrm{I}$ ) and occupied a greater space within the spore. The Plistophora spore walls formed a striking contrast to the smooth ones of the Thelohania species, their major component being a packed array of tubules, which were splayed out in the spore and lay parallel to each other in the sporoblast. This type of spore wall was seen by Vavra (1965) in Plistophora debaisieuxi, also from Simulium larvae.

There was no evidence of dormant sporonts (Hazard \& Weiser, I968) in the Thelohania material examined, the parasitized tissues all containing developing sporonts (Fig. I).

We were unable to resolve the question as to whether all the spores contained two nuclei. Huger (1960) believed that a binucleate condition was typical of Nosema locustae. Fig. 9 shows two nuclear profiles but the possibility of a section passing through a single curved nucleus could not be eliminated. 

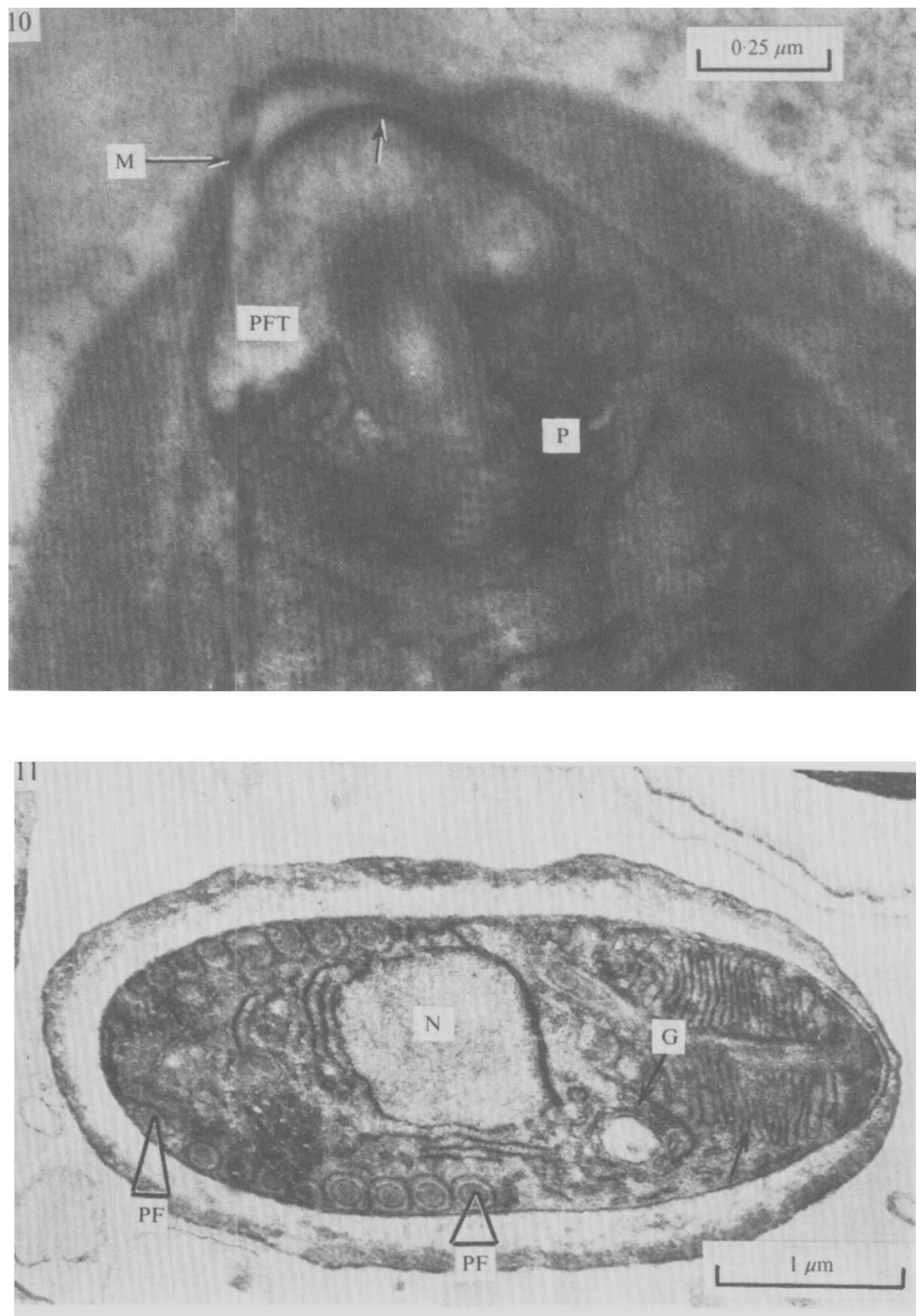

Fig. 10. The extreme anterior end of a mature spore of Thelohania minuta, showing the mushroomlike termination of the polar filament (PFT) beneath the micropyle (M). The layer of cytoplasm between the spore wall and the termination is arrowed.

Fig. I I. A mature spore of the Thelohania canningi with ten polar filament coils (PF). The junctions of the polaroplast lamellae at their outer edges are arrowed. An area similar to a Golgi apparatus $(G)$ is shown. 

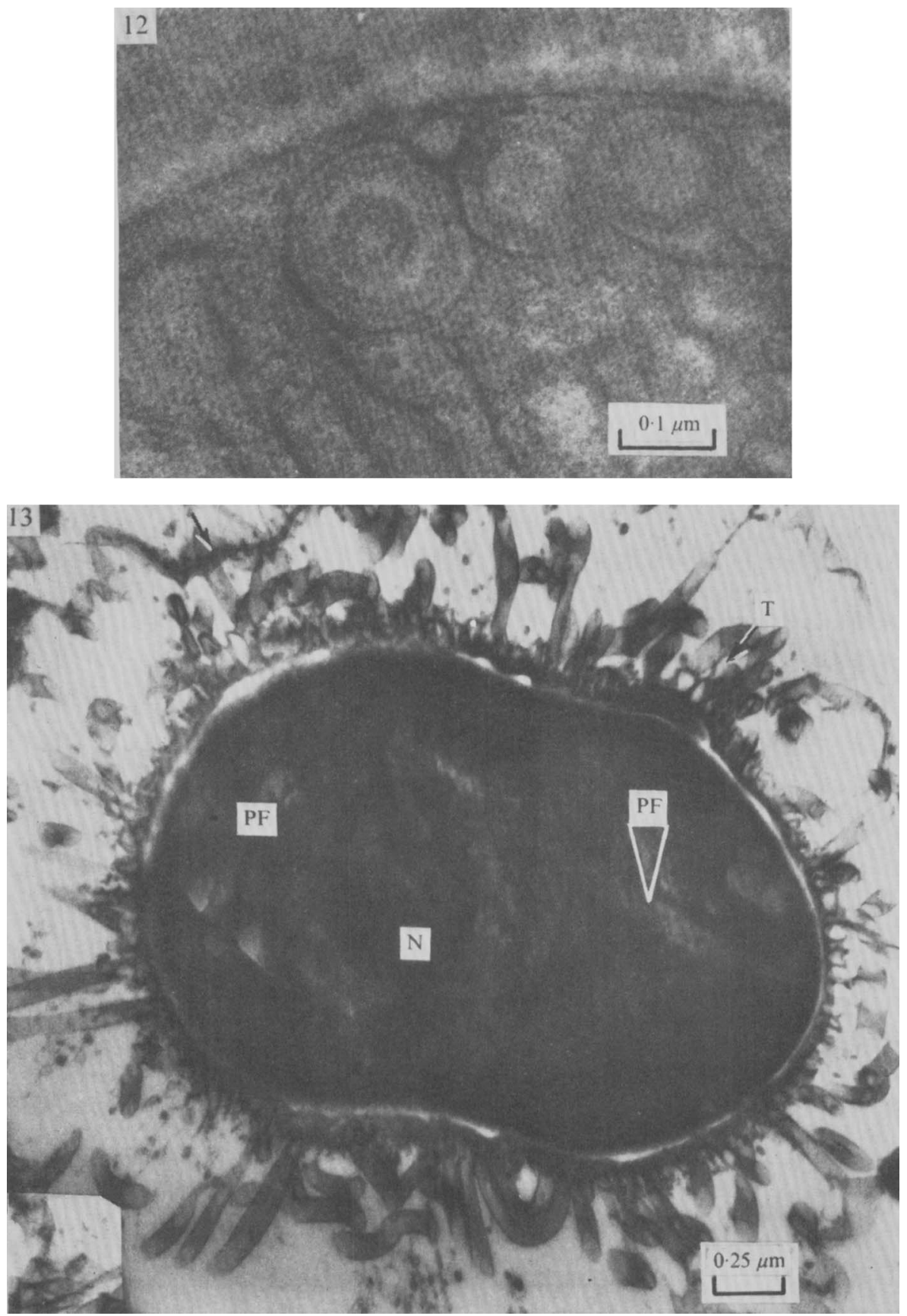

Fig. 12. An area enlarged from Fig. 9 of the contents of the polar filament, here seen as concentric rings in cross section.

Fig. 13. A mature spore of Plistophora tillingbournei, showing the complex tubular (T) structure of the spore wall. The remains of the original outer layer is arrowed. 
We did establish that in the Thelohania spores the polar filament within the spore contains several concentric rings of material (Fig. 12). This makes the concept of the sporoplasm passing through the filament after extrusion, and the suggestion that the polar filament turns inside out during protrusion, difficult to support. All the spores examined had a layer of cytoplasm separating the mushroom-shaped polar cap of the polar filament from the internal spore wall. The spore wall was very thin in this area, presumably in preparation for the extrusion of the filament. But the presence of this cytoplasmic layer would indicate poor direct attachment of the cap to the spore wall, resulting in little purchase for any mechanical torque or traction required for extrusion. No fibrils or specialized attachments were found. We could find no structures which could explain a mechanical method of extrusion.

The lamellae of the polaroplast were less tightly packed than those reported for the species of Nosema (Stanier et al. 1968). The extensive membrane systems in addition to the polaroplast would suggest a very active endoplasmic reticulum for a resting spore. Together perhaps they act as sites for energy production, since no recognizable mitochondrial system was found.

Acknowledgement is due to Dr R. G. Bird, Director, Electron Microscope Laboratory, and to Professor D. S. Bertram of the Department of Entomology for facilities to carry out this work; to the Government of the Sudan, the Ministry of Overseas Development of the British Government, and the World Health Organization for financial support; to the Government of Sudan for leave of absence for M.S.S.G.; and to Miss Carol Upton and Mr David Day for technical and photographic assistance.

\section{REFERENCES}

AKaO, S. (1969). Studies on the ultrastructure of Nosema cuniculi, a microsporidian parasite of rodents. Japanese Journal of Parasitology 18, 8-20.

Gassouma, M.S.S. (I972). Microsporidan parasites of Simulium ornatum Mg. in southern England. Parasitology 65, 27-45.

Hazard, E. I. \& Weiser, J. (1968). Spores of Thelohania in adult female Anopheles: development and transovarial transmission, and redescriptions of T. legeri Hesse and T. obesa Kudo. Journal of Protozoology $15,814-823$.

Huger, A. (1960). Electron microscope study on the cytology of a microsporidian spore by means of ultrathin sectioning. Journal of Insect Pathology 2, 84-105.

ISHIHARA, R. (1968). Some observations on the fine structure of sporoplasm discharged from spores of a microsporidian, Nosema bombycis. Journal of Invertebrate Pathology 11, 377-385.

Kudo, R. R. \& Daniels, E. W. (I963). An electron microscope study of the spores of a microsporidian Thelohania californica. Journal of Protozoology ro, 1 I $2-120$.

Lainson, R., Garnham, P. C. C., Killick-Kendrick, R. \& Bird, R. G. (1964). Nosematosis and microsporidial infection of rodents and other animals including man. British Medical Journal 2, 470-472.

LOM, J. \& Corliss, J. C. (1967). Ultrastructural observations on the development of the microsporidian protozoan, Plistophora hyphessobryconis Schaperclaus. Journal of Protozoology 14, 14I-I52.

Lom, J. \& VAVRA, J. (I96I). Niektore wyniki badan nad ultra-struktura spor pasozyta ryb Plistophora hyphessobryconis (Microsporidia). Wiadomości parazytologiczne 7, 828-832.

Lom, J. \& VAVRA, J. (1963). Fine morphology of the spore in microsporidia. Acta protozoologica $\mathbf{r}$, I 79-283.

Sprague, V. \& Vernick, S. H. (I968a). Light and electron microscope study of a new species of Glugea (Microsporidia: Nosematidae) in the 4-spined stickleback Apeltes quadracus. Journal of Protozoology I5, 547-57I.

Sprague, V. \& Vernick, S. H. (1968b). The Golgi complex of microsporidia and its role in spore morphogenesis. American Zoologist 8, 823-824.

Sprague, V. \& Vernick, S. H. (1969). Light and electron microscope observations on Nosema nelsoni Sprague, I950 (Microsporidia: Nosematidae) with particular reference to its Golgi complex. Journal of Protozoology 16, 264-271. 
Sprague, V., Vernick, S. H. \& Bolivar, J. L. Jun. (1968). The fine structure of Nosema sp. Sprague 1965 (Microsporidia: Nosematidae) with particular reference to stages in sporogony. Journal of Invertebrate Pathology 12, I05-117.

Stanier, J. E., Woodhouse, M. A. \& Griffin, R. L. (I968). The fine structure of the spore of Nosema spelotremae, a microsporidian parasite of a Spelotrema metacercaria encysted in the crab Carcinus maenas. Journal of Invertebrate Pathology 12, 73-83.

VAVRA, J. (1965). Étude au microscope électronique de la morphologie et du développement de quelques Microsporidies. Compte rendu de l'Académie des sciences 261, 3467-3470.

VAVRA, J. (I968). Ultrastructural features of Caudospora simulii Weiser (Protozoa: Microsporidia). Folia parasitologica 25, I-9.

Vernick, S. H., Sprague, V. \& Bolivar, J. L. Jun. (I969). Further observations on the fine structure of the spores of Glugea weissenbergi (Microsporidia: Nosematidae). Journal of Protozoology 16, 50-53. 